\title{
Pengaruh Pendekatan Student Centered Learning Terhadap Kemampuan Mengidentifikasi Tumbuhan di Hutan Taman Eden 100 Mahasiswa Pendidikan Biologi FKIP UISU Medan.
}

\author{
${ }^{(1)}$ Nurhayati, (2)Pandu Prabowo Warsodirejo, S.Pd, M.Pd \\ Alumni Prodi Pendidikan Biologi FKIP UISU ${ }^{(1)}$, Dosen Program Studi Pendidikan Biologi FKIP UISU(2) \\ nurhayati@gmail.com, panduprabowo@fkip.uisu.ac.id
}

\begin{abstract}
ABSTRAK
Penelitian ini bertujuan untuk mengetahui adakah pengaruh Pendekatan Student Centered Learning Terhadap Kemampuan Mengidentifikasi Tumbuhan Di Hutan Taman Eden 100 Pada Mahasiswa Pendidikan Biologi FKIP UISU Medan. Penelitian ini dilaksanakan pada bulan Maret-Juni 2018. Penelitian ini menggunakan Metode Eksperiment Semu (Quasi experimen) dengan populasi penelitian adalah seluruh mahasiswa Pendidikan Biologi FKIP UISU Medan yang berjumlah 103 mahasiswa yang kemudian dijadikan sampel sebanyak 21 mahasiswa semester 4 Pendidikan Biologi dengan cara pengampilan sampel dengan teknik Non Probability sampling dengan cara pertimbangan tertentu (sampling Purposive). Data yang dianalisis dalam penelitian ini adalah berupa test tertulis yaitu pre test dan post test pada materi vegetasi tumbuhan mata kuliah Ekologi Tumbuhan. Nilai rata-rata pre test sebelum pendekatan Student Centered Learning adalah 50,21 dan standar deviasi 13,07 maka mahasiswa yang termasuk kategori baik sebanyak 3 orang $(14,28 \%)$ dan 18 orang termasuk kategori kurang $(85,71 \%)$. Dan rata-rata post test yang diperoleh setelah pendekatan Student Centered Learningyang diterapkan adalah 69,92 dan standar deviasi adalah 7,32 maka mahasiswa yang termasuk kategori baik sebanyak 14 orang mahasiswa (67\%) dan 7 orang termasuk kategori kurang (33\%). Berdasarkan uji hipotesis diperoleh thitung $=6,92$ sedangkan nilai ttabel $=1,72$ jadi thitung $>$ ttabel, maka Ha diterima dan H0 ditolak, dan dapat disimpulkan bahwa ada pengaruh signifikan menggunakan Pendekatan Student Centered LearningTerhadap Kemampuan Mengidentifikasi Tumbuhan Di Hutan Taman Eden 100 pada Mahasiswa Pendidikan Biologi FKIP UISU Medan.
\end{abstract}

Kata Kunci : Student Centered Learning, Kemampuan Mengidentifikasi Tumbuhan, Vegetasi Tumbuhan

\begin{abstract}
This study aims to determine whether there is the influence of Student Centered Learning approaches to the ability to identify plants in Taman Eden 100 forest in Biology Educations Students FKIP UISU Medan. This research was conducted in March - June 2018. This research used quasi Experiment method with research population is all college students Biology Educations FKIP UISU Medan which amounted to 103 students which then made as many as 21 students from Semester 4 Biology Educations by way of Non Probability Sampling technique with Purposive Sampling. The data analyzed in research is a written test that is pre test and post test on vegetation of plants material courses plant Ecology. The average value of pre test before applied the Student Centered Learning approaches is 50,21 and standard deviation 13,07 then as many good categories 3 people $(14,28 \%)$ and 18 people including less categories $(85,71 \%)$. And the average post test is obtained after the applied the Student Centered Learning approaches is 69,92 and standard deviation is 7,32
\end{abstract}


Nurhayati, Prabowo P : Pengaruh Pendekatan Student Centered Learning Terhadap Kemampuan Mengidentifikasi Tumbuhan di Hutan Taman Eden 100 Mahasiswa Pendidikan Biologi FKIP UISU Medan

then students as many good categories is 14 people (67\%) and 7 people including less categories (33\%). Based on the hypothesis test obtained tcount $=6,92$ while the value ttable $=1,72$ so tcount $>\mathrm{t}$ table, thus Ha accepted and H0rejected, and it can be concluded that there is significant effect of using the Student Centered Learning approaches to the ability to identify plants in Taman Eden 100 forest in Biology Educations College Students FKIP UISU Medan

Keywords : Student Centered Learning, Ability to Identify Plants,Vegetation of Plants

\section{PENDAHULUAN}

\section{Latar Belakang}

Seiring perkembangan zaman kualitas sistem pendidikan semakin meningkat. Komitmen dan keharusan dalam meningkatkan kualitas pendidikan sangat penting untuk mengatasi fenomena turunnya kualitas pendidikan. Metode pembelajaran masa lalu, mahasiswa hanya mendengarkan penjelasan materi dari dosen. Mahasiswa hanya sebatas memahami penjelasan dosen dan membuat catatan. Menurut Sudjana (2005:23) Prestasi belajar adalah kemampuan yang diperoleh mahasiswa setelah mereka menerima pengalaman belajar. Rendahnya pemahaman mahasiswa terhadap mata kuliah yang diambil mengakibatkan prestasi belajarnya tidak optimal. Kurangnya pemahaman pada setiap mata kuliah menyebabkan para mahasiswa kesulitan memecahkan kasus-kasus yang diberikan oleh dosen. Permasalahan pedagogik yang dikritik dalam Pendidikan Biologi adalah berhubungan dengan cara mengajar sebagai berikut ini (1) Banyak menekankan pada proses menghapalkan; (2) Tidak banyak menggunakan pengalaman di luar kelas; (3) Kurangnya memberikan keahlian berpikir yang cukup relevan kepada mahasiswa; (4) Terlalu banyak lecturing, menekankan pada materi buku teks dan cara pembelajaran konvensional lainnya; (5) Keengganan untuk menciptakan pembelajaran yang kreatif seperti bekerja team, analisis kasus dan lain-lain. (6) Terlalu menyederhanakan masalah dengan melihat permasalahan-permasalahan dalam pendidikan Biologi sebagai sesuatu yang terstruktur dan sudah jelas. Dalam upaya meningkatkan kualitas pendidikan di perguruan tinggi, tersedianya sumberdaya yang baik dan memadai tidaklah cukup. Tersedianya sumberdaya yang baik dan memadai harus juga dikaitkan dengan aturan agar menghasilkan kinerja yang baik. Khusus sumberdaya manusia, sikap, kepedulian dan kehendak mencapai kualitas merupakan persyaratan yang sama pentingnya dengan kemampuan ilmiah. Metode pembelajaran saat ini belum dapat mengasah kemampuan analisis mahasiswa, kepekaan terhadap permasalahan, kemampuan pemecahan masalah, dan kemampuan untuk mengevaluasi permasalahan. Penilaian kualitas dari sebuah produk pendidikan pertama-tama dapat terlihat pada perkembangan sikap dasar, seperti sikap kritis akademis ilmiah dan kesediaan untuk selalu mencari kebenaran. Konsep pendidikan tidak dapat direduksi hanya dengan cara ujian karena hal tersebut hanya mengukur transfer pengetahuan, akan tetapi mencangkup pembentukan keterampilan (skill) dan sikap dasar (basic attitude), seperti kekritisan, kreativitas dan keterbukaan terhadap inovasi dan aneka penemuan. HEALTS (Higher Education Long Term Strategy) atau Strategi Jangka Panjang Pendidikan Tinggi 2003-2010 yang dikeluarkan oleh Direktur Jenderal Pendidikan Tinggi pada bulan April 2003 memberi amanah yang salah satunya adalah penerapan prinsip Student-Centered Learning dalam proses pembelajaran. Terdapat beragam metode pembelajaran untuk SCL dan satu diantaranya adalah Discovery Learning. Menurut Peter Drucker (1967) dalam buku Pengolahan Belajar Ivor K. Davies (1986:154) Pemilihan strategi mengajar yang tepat merupakan masalah efektivitas. Hal ini meliputi bagaimana mengelola lima hal, yaitu: Pengolahan waktu; pemilihan apa yang harus disampaikan; mengetahui dimana dan bagaimana menerapkan kekuatan yang efektif mungkin; 
Nurhayati, Prabowo P : Pengaruh Pendekatan Student Centered Learning Terhadap Kemampuan Mengidentifikasi Tumbuhan di Hutan Taman Eden 100 Mahasiswa Pendidikan Biologi FKIP UISU Medan

menentukan prioritas yang tepat dan kemudian menjalin semua itu yang satu dengan yang lain untuk memperoleh keputusan yang efektif. Selama ini masih banyak mahasiswa kurang mampu menghubungkan apa yang dipelajari dengan bagaimana pengetahuan yang diperolehnya untuk dimanfaatkan. Pada hal yang diharapkan adalah pembelajaran merupakan proses pengkondisian yang menyentuh realitas alami. Pembelajaran Biologi adalah pembelajaran yang menekankan pada pemberian pengalaman secara langsung, karena itu mahasiswa perlu untuk mengembangkan sejumlah keterampilan supaya mahasiswa mampu menjelajahi dan memahami alam sekitar. Keterampilan ini meliputi keterampilan mengamati dengan seluruh indera, mengajukan pertanyaan menggolongkan, menafsirkan data dan mengkomunikasikan hasil temuan secara beragam, mengali dan memilih informasi faktual yang relevan untuk menguji gagasan- gagasan atau pemecahan masalah sehari-hari, jadi pada dasarnya pembelajaran Biologi berupaya untuk membekali mahasiswa dengan berbagai kemampuan tentang cara mengetahui dan cara mengerjakan yang dapat membantu mahasiswa untuk memamahi alam sekitar secara mendalam. Alam sebagai natural resources dimana mahasiswa langsung berinteraksi untuk mengamati dan melestarikan sehingga dapat meningkatkan berpikir ilmiah, mahasiswa dituntut untuk belajar aktif yang terimplikasi dalam kegiatan secara fisik maupun mental. Pendekatan pembelajaran berpusat pada mahasiswa (SCL) merupakan salah satu pendekatan pembelajaran yang sangat efektif dalam meningkatkan proses pembelajaran. Wisudawati dan Sulistiyawati (2014:130) mengatakan bahwa pendekatan Student Centered Learning merupakan pembelajaran aktif dimana pendidik berperan sebagai fasilitator, motivator, katalisator dan pengontrol konsep. Maka sebagai seorang pendidik harus dapat melaksanakan pembelajaran yang bersifat PAILKEM sesuai konsep pembelajaran Aktif, Inovatif, Lingkungan, Kreatif, Efektif dan Menyenangkan. Pembelajaran PAILKEM berbasis Student Centered Learning. Dalam konsep PAILKEM, dapat memanfaatkan lingkungan sebagai tempat atau sumber belajar. Maka dari itu, program studi Pendidikan Biologi FKIP UISU mencoba menerapkan pembelajaran yang berpusat pada mahasiswa (Student Centered Learning)

\section{Perumusan Masalah}

Berdasarkan uraian dalam latar belakang masalah, identifikasi masalah, maka dapat dirumuskan masalah penelitian yaitu sebagai berikut: Apakah ada pengaruh signifikan pada pendekatan Student Centered Learning terhadap tingkat kemampuan mengidentifikasi tumbuhan di hutan Taman Eden 100 pada mahasiswa Pendidikan Biologi FKIP UISU Medan?

\section{Tujuan Penelitian}

Berdasarkan rumusan masalah di atas, maka tujuan penelitian ini adalah :

1. Untuk mendapatkan data kemampuan mahasiswa dalam mengidentifikasi tumbuhan sebelum menggunakan pendekatan Student Centered Learning pada mahasiswa Pendidikan Biologi FKIP UISU Medan.

2. Untuk mendapatkan data kemampuan mahasiswa dalam mengidentifikasi tumbuhan setelah menggunakan pendekatan Student Centered Learning pada mahasiswa Pendidikan Biologi FKIP UISU Medan.

3. Untuk mendapatkan data pengaruh pendekatan Student Centered Learning terhadap tingkat kemampuan mengidentifikasi tumbuhan di hutan pada mahasiswa Pendidikan Biologi FKIP UISU Medan 
Nurhayati, Prabowo P : Pengaruh Pendekatan Student Centered Learning Terhadap Kemampuan Mengidentifikasi Tumbuhan di Hutan Taman Eden 100 Mahasiswa Pendidikan Biologi FKIP UISU Medan

\section{Manfaat Penelitian}

Sejalan dengan tujuan penelitian di atas maka manfaat penelitian ini adalah :

1. Bahan masukan bagi Dosen : Sebagai alat bantuan untuk memecahkan masalah yang sering ditemukan di dalam kelas, sehingga dapat melakukan inovasi dalam mengatasi berbagai permasalahan pembelajaran yang dihadapi dalam ruang kelas.

2. Bagi mahasiswa : Sebagai bahan untuk meningkatkan hasil kemampuan belajar serta memberi pengalaman terbaik bagi mahasiswa Pendidikan Biologi dalam menerima pembelajaran baik di dalam kelas atau di luar kelas.

3. Bagi peneliti : Mendapat pengalaman langsung pelaksanaan pembelajaran Biologi yang efektif dalam meningkatkan kemampuan pemahaman konsep, penalaran, serta sebagai bekal untuk digunakan peneliti setelah menjadi guru.

4. Bagi pembaca : Memberikan informasi mengenai model pembelajaran dan sebagai bahan masukan sekaligus perbandingan untuk penelitian.

\section{METODE PENELITIAN}

Desain penelitian yang digunakan adalah Eksperimen semu (Quasi Eksperiment) yaitu penelitian yang dimaksudkan untuk mengetahui ada tidaknya akibat dari suatu yang dikenakan pada subjek yaitu mahasiswa.

\section{Tabel Rancangan Desain Penelitian}

\begin{tabular}{|l|l|l|l|}
\hline Kelas & Pre Test & Perlakuan & Post Test \\
\hline Semester 4 & T1 & Student Centered Learning & $\mathrm{T}_{2}$ \\
\hline
\end{tabular}

Keterangan :

T1 : Hasil Pre Test pada kelas Biologi Semseter 4 sebelum diberi perlakuan dengan menggunakan pendekatan Student Centered Learning.

SCL : Perlakuan yang diberikan pada sampel selama penelitian berlangsung

T2 : Hasil Post Test pada kelas Biologi Semester 4 setelah diberi perlakuan dengan menggunakan pendekatan Student Centered Learning.

Quasi eksperimen atau yang disebut juga desain eksprimen semu, adanya interaksi pengajar dengan mahasiswa dan mahasiswa dengan mahasiswa menggunakan pendekatan pembelajaran yang digunakan yaitu pendekatan Student Centered Learning, dengan mengabaikan faktor-faktor lain seperti latar belakang mahasiswa, jenis kelamin, kecerdasan, dan lain sebagainya. Kemudian penelitian ini memiliki Prosedur Penelitian yaitu sebagai berikut :

1. Tahap Persiapan

Adapun kegiatan yang dilakukan pada tahap persiapan ini antara lain :

a. Mengadakan observasi lapangan ke hutan tempat penelitian

b. Pengurusan surat izin penelitian dari Fakultas Keguruan dan Ilmu Pendidikan Universitas Islam Sumatera Utara.

c. Mencari literatur/kajian pustaka yang relevan sesuai dengan materi penelitian yang akan dilakukan. 
Nurhayati, Prabowo P : Pengaruh Pendekatan Student Centered Learning Terhadap Kemampuan Mengidentifikasi Tumbuhan di Hutan Taman Eden 100 Mahasiswa Pendidikan Biologi FKIP UISU Medan

d. Berkonsultasi dengan Dosen pembimbing tentang memilih anggota kelas yang akan digunakan sebagai populasi dan sampel.

e. Menyusun proposal Penelitian yang akan dilakukan.

f. Membuat kisi - kisi soal dalam bentuk pilihan ganda dari materi yang akan diujikan sebagai instrumen penelitian.

g. Mengikuti seminar proposal

2. Tahap Pelaksanaan

Adapun kegiatan yang dilakukan pada tahap pelaksanaan ini antara lain:

a. Menentukan kelas yang akan dijadikan populasi dan sampel penelitian yaitu mahasiswa pendidikan Biologi semester 4.

b. Memberikan Pre-Test kepada mahasiswa sebelum mahasiswa dibawa untuk studi langsung ke lapangan untuk mengetahui sejauh mana kemampuan dasar mahasiswa dalam mempelajari mata kuliah Ekologi Tumbuhan..

c. Membawa mahasiswa yang dijadikan sebagai sampel penelitian ke hutan Taman Eden 100 Lumban Julu dalam penerapan pendekatan pembelajaran Student Centered Learning.

d. Mahasisawa diajarkan materi kuliah Ekologi Tumbuhan yang langsung bersumber dari alam yaitu hutan Taman Eden 100 Lumban Julu.

e. Mahasiswa mulai mengidentifikasi Tumbuhan yang ada di sekitar hutan Taman Eden 100 Lumban Julu yang berkaitan dalam mata kuliah Ekologi Tumbuhan.

3. Tahap penyelesaian

Adapun kegiatan yang dilakukan pada tahap penyelesaian ini antara lain :

a. Melakukan pengolahan data dari hasil penelitian.

b. Melakukan proses analisis data dari hasil penelitian.

c. Menarik kesimpulan dari hasil penelitian.

d. Menyusun laporan dengan melengkapi lampiran-lampiran yang berhubungan dengan penelitian

\section{HASIL DAN PEMBAHASAN}

Berdasarkan hasil dari perhitungan data pada pre test yang diberikan di semester 4 Pendidikan Biologi FKIP UISU Medan diperoleh data 14,20\% mahasiswa dinyatakan tuntas dan $85,71 \%$ tidak tuntas. Dengan nilai tertinggi 70 sebanyak 3 orang dan nilai terendah 30 sebanyak 4 orang, dengan nilai rata-rata pre test 50,21 dengan kreteria kemampuan mengidentifikasi tumbuhan 70 dan standart deviasi 13,07. Setelah diberi pengajaran dengan pendekatan Student Centered Learning dengan menggunakan model Discovery Learning pada mahasiswa Pendidikan Biologi FKIP UISU Medan yang mendapat nilai tertinggi 80 sebanyak 6 orang dan nilai terendah 60 sebanyak 6 orang. Maka mahasiswa yang tuntas sebanyak 14 orang $(67 \%)$ dan 7 orang (35\%) mahasiswa yang tidak tuntas, dengan nilai rata-rata $69,92 \%$ dengan kreteria kemampuan mengidentifikasi tumbuhan 70 dan standart deviasi 7,32. Berdasrkan hasil perhitungan data saat pre test dan post test diketahui dengan penggunaan Pendekatan Student Centered Learning dengan model Discovery Learning terhadap kemampuan mengidentifikasi tumbuhan di hutan Taman Eden 100 pada mahasiswa pendidikan Biologi FKIP UISU Medan. Adapun kemampuan awal mahasiswa dari nilai rata-rata masih dibawah kreteria kemampuan mengidentifikasi yang ditentukan yaitu 70. Hal ini disebabkan karena pada pelaksanaan pre test mahasiswa diberikan soal tanpa sebelumnya dilakukan penerapan pembelajaran dengan Pendekatan Student Centered Learning. Sedangkan data hasil kemampuan mengidentifikasi tumbuhan setelah menggunakan pendekatan Student Centered Learning dengan model Discovery Learning dengan pemberian post test 
Nurhayati, Prabowo P : Pengaruh Pendekatan Student Centered Learning Terhadap Kemampuan Mengidentifikasi Tumbuhan di Hutan Taman Eden 100 Mahasiswa Pendidikan Biologi FKIP UISU Medan

mahasiswa semeseter 4 Pendidikan Biologi FKIP UISU Medan diperoleh nilai rata-rata 69,92 dan dapat dilihat bahwa terjadi peningkatan kemampuan mengidentifikasi tumbuhan setelah menggunakan pendekatan Student Centered Learning dengan model Discovery Learning. Peningkatan ini terjadi karena pendekatan Student Centered Learning langsung membawa mahasiswa langsung dibawa ke lapangan dan pembelajaran tentang mengidentifikasi ini disukai oleh mahasiswa, walaupun peningkatan kemampuan mahasiswa dalam mengidentifikasi tumbuhan belum maksimal, karena hanya sekitar $67 \%$ saja. Peningkatan yang belum maksimal ini dikarenakan waktu pengajaran yang terlalu singkat, dan saat membawa mahasiswa dalam belajar di alam juga tidak terlalu lama.

\section{DAFTAR PUSTAKA}

Al-Qur'an Surah Az-Zumar, ayat 9

Arikunto. S. 2016. Prosedur Penelitian Suatu Pendekatan Pratik. Jakarta:Rineka Cipta

Arsyad, A. 2013. Media Pembelajaran. Jakarta : Raja Grafindo Persada

Arief, A. 1994. Hutan Hakekat dan Pengaruhnya Terhadap Lingkungan. Jakarta: Yayasan Obor Indonesia Jakarta

Aunurrahman. 2012. Belajar dan Pembelajaran. Bandung: Alfabeta

Dwidjoseputro. 1994. Ekologi manusia dengan lingkungannya. Jakarta: Penerbit Erlangga.

Ginanjar, Ary Agustian (2002). Emotional Spritual Quotient (ESQ). Jakarta:

Arga.

_http://www.google.com/search/ekologitumbuhan (diakses pada tanggal 27 Februari 2018 pukul 21:00 WIB)

Harsono. 2004. Kearifan dalam transformasi pembelajaran: dari teacher-centered ke student-centered learning. Jakarta: Seminar Pendidikan

Mohamad, N dan Uno. B. H. 2011. Belajar Dengan Pendekatan Pailkem. Jakarta : Bumi Aksara.

Odum, EP. 1983. Basic Ecology. Sounders: Philadelphia

Resosoedarmo, Soedjiran. 1985. Pengantar Ekologi. Jakarta : Remadja Karya

Sagala, S. 2013. Etika dan Moralitas Pendidikan. Jakarta : Prenadamedia Group Jakarta ; Rineka Cipta

Sanjaya, W. 2012. Media Komunikasi Pembelajaran. Jakarta: Kencana Premedia Group 
Nurhayati, Prabowo P : Pengaruh Pendekatan Student Centered Learning Terhadap Kemampuan Mengidentifikasi Tumbuhan di Hutan Taman Eden 100 Mahasiswa Pendidikan Biologi FKIP UISU Medan

Soerianegara, I dan Indrawan, A. 1988. Ekologi Hutan Indonesia. Bogor: Laboratorium Ekologi Fakultas Kehutanan, IPB

Slameto. 2010. Belajar dan Faktor - faktor yang mempengaruhi. Jakarta: Rineka Cipta Sudjana. 2002. Metoda Statistika. Bandung: Tarsito. 